\title{
BIOREMEDIATION OF PETROLEUM PRODUCTS CONTAMINATED SOIL
}

\author{
Miaskiewicz-Peska E. \\ Lebkowska M., \\ Sztompka E., \\ Muszynski A., \\ Karwowska E., \\ Warsaw University of Technology, Poland
}

\begin{abstract}
A method for bioremediation of petroleum derivatives contaminated soil was presented. It was applied in field conditions since 1993 to 1998. Results of the research work over petrol, oil and jet fuel biodegradation in soil were discussed. It was found out that efficiency of the process of biodegradation depends on the extent and kind of petroleum products contamination as well as a type of soil. It was demonstrated that the biological method applied in the research work allows to remove $80-99 \%$ of the hydrocarbons within $22-74$ days.
\end{abstract}

\section{INTRODUCTION}

Bioremediation of petroleum products contaminated soil consists in the application of the appropriate technical parameters enabling high efficiency of the microbial degradation of hydrocarbons. Progress of the process depends on the physical and chemical properties of soil, migration of the contaminants combined with water migration, kind and concentration of petroleum derivatives and right selection of bacterial strains. Wide spectrum of problems connected with a technological procedure of biological soil remediation designing makes collaboration of microbiologists, chemists, geologists, engineers-specialists of sanitary engineering absolutely essential.

Before it is decided that soil is to be subjected to bioremediation, the area of spread contamination should be defined, basing on the soil characteristics. If the concentration of petroleum products is high they should be eliminated to the level lower than $10 \%$, preferably not higher than $5 \%$. The progress of the hydrocarbons biodegradation depends on the chemical structure of hydrocarbons, their toxicity, solubility, dispersion in water and sorption in soil particles. Therefore application of sensitive instruments to analyse the quantity and quality of hydrocarbons, for instance gas chromatography and infrared spectrophotometry is indispensable. 
It is a well-known fact, that the most susceptible to biodegradation are linear-chained alkanes containing $\mathrm{C}_{10}-\mathrm{C}_{22}$ atoms, simple benzen derivatives and monocykloalkanes Cycloalkanes, policyclic aromatic hydrocarbons and PAH's containing more than 4 rings are resistant to degradation [2][5][6].

The choice of bioremediation conditions requires also information about physicochemical properties of soil, for example granulometric composition, total and field water capacity, $\mathrm{pH}$, salinity, organics concentration (including pesticides), cation exchange capacity, contents of nitrogen and phosphorus [3].

When autochtonic bacteria are to be employed for cleaning up soil they should be isolated and identified. Next, only those able to metabolise hydrocarbons present in contaminated soil as the only source of carbon and energy ought to be left except potentially pathogenic strains.

Application of the autochtonic microbes is more efficient, cheaper and safer for environment than use of ready-made biopreparations [7]. Biopreparations may contain altered microorganisms - their introduction to the natural environment is not in practice in the world so far [1].

The choice of bioremediation strategy depends first of all on the type of soil. The extracting method "in situ" does not require soil removal but is suitable for sandy soil - easily permeable to water. "Ex situ" cleaning up allows to treat sandy and clayey soil. The rate of biological decomposition of hydrocarbons depends on soil-moisture, temperature, oxygenation, etc; data review is presented by Lebkowska [4].

The paper presents results of the lab and field research works of bioremediation of petroleum products contaminated soil performed by the Department of the Environmental Biology of Warsaw University of Technology and EXBUD Hydrogeotechnika Comp.Ltd.

\section{PRINCIPLE OF THE METHOD}

The method consists in isolation of microorganisms from petroleum derivatives contaminated soil and selection of those capable of using contaminating hydrocarbons as the only source of carbon and energy. Next, chosen isolates are multiplied and introduced into soil in the biomass which range from $10^{7}$ to $10^{8}$ cells/g soil dry weight.

Contaminated soil was excavated and then a prism was formed on geomembranes. Afterwards, free or immobilised in granulated clay bacterial cells were introduced into soil as well as water solution of a mineral fertilizer containing nitrogen and phosphorus. Finally, soil was dug over by hand or by means of excavator to aerate and mix it or special aerating equipment was employed. Dose of nitrogen and phosphorus and frequency of bacteria introduction were related to the results of initial checks. Prism aeration was done when it appeared necessary after microbial and chemical analysis. The cleanup process was proceeded until hydrocarbons concentration decreased to the values compatibile with the assumptions or guidelines from the State Environmental Inspectorate [8]. 


\section{RESULTS OF BIOREMEDIATION WORKS}

Results are presented in Table 1.

Field researches done at the petrol station in Kielce-Bialogon (No 1-3) regarded estimation of the ground wetness influence on the cleanup effect (No 1-2 - a not moistened prism, No 3 - a moistened one). Bacteria immobilised in granulated clay as well as free cells were applied once. Despite the differences in the initial hydrocarbons concentration and lack of mechanical aeration, the shortest time of bioremediation was reported in case of the prism where moisture measurements were done and water supplemented (No 3). In case of other cleanup works, done mostly "ex situ" - in prisms (No 5-8) the frequency of bacteria introduction was increased, soil was mixed and water supplemented to keep moisture at the level of $70 \%-80 \%$ of the maximum water capacity. The effect of fuel oil elimination was high and reached $84 \%-96 \%$ within 24-45 days. Residuals of other hydrocarbons were in the concentrations close to these admitted by the State Environmental Inspectorate for mineral oils ( B type area).

Bioremediation of soil at Kluczewo airport was carried out for two main types of contaminants - jet fuel (No 9 and 12) and fuel oil (No 10 and 11). Jet fuel was eliminated in 95\% within 22 days. In prisms contaminated with fuel oil additional unidentified chemicals - oil and grease were detected. It resulted in a long time of cleaning up which reached 56-74 days. High level of bioremediation in the prism containing soil polluted after the transfer pipeline had been bored (No 12) - the hydrocarbons concentration decreased from $31400 \mathrm{mg} / \mathrm{kg}$ to about $90 \mathrm{mg} / \mathrm{kg}$ ( $99.7 \%$ of reduction) - probably resulted from the homogenity of the contamination (jet fuel ) its decomposition susceptibility, temperature (higher than $20^{\circ} \mathrm{C}$ ); time of duration was 1 month.

As compared in Table 1, the most resistant to biochemical decomposition was crude petroleum (No 4). Inside the prism asphalt clods and other heavy fractions of petroleum were found. In the upper layer of the prism reduction of contaminants reached $80 \%$, in the lower one $60 \%$. Soil containing naphtalene and asphalt fractions cannot undergo microbiological reclamation.

Bioremediation of petrol contaminated soil depends on soil structure and depth of the pollutant migration. Application of soil ventilation allows to blow out light ends of petrol; it was not technically feasible in case of No 13 and 14. Petrol contamination present in a 2-meter layer was decomposed in $80 \%-93 \%$ after 80 days. It was observed that sandy soil was cleaned up more effectively than clayey one.

In bioremediation strategy presented in this paper following bacterial strains were applied: Bacillus sp., Alcaligenes faecalis, A. xylosooxidans, Sphingomonas paucimobilis, Pseudomonas fluorescens, Ps. mendocina, Ps. alcaligenes, Ps. diminuta, Ps. putida, Ps. stutzeri, Micrococcus sp., M. varians, Acinetobacter lwoffii, Flavobacterium meningosepticum, Chryseomonas luteola. Usually 3-5 active bacterial strains able to dominate in soil as reclamation proceeded were introduced as an inoculum. Decrease in the content of hydrocarbons resulted in a reduction of the amount of microorganisms from $10^{7}-10^{8}$ to $10^{3}-10^{4}$ cells /g dry weight.

It was found out that population of bacteria capable of utilising petroleum derivatives as the only source of carbon appeared a tiny fraction $(0.01-2.2 \%)$ of the total number of bacteria inhabiting polluted soil.

No correlation was observed for type of soil and bacterial dominants in autochtonic microflora. Pseudomonas species were isolated as dominating bacteria both in clayey and sandy soil. The same was observed in case of Micrococcus species. Bacillus species and Agrobacterium radiobacter occured twice in bioremediated soil. Comamonas testosteroni, Chromobacterium 
violaceum, Flavobacterium indologenes, Staphylococcus saprophiticus and Acinetobacter lwoffii appeared the smallest fraction among the isolates.

It appeared that if contamination consists of light fraction of hydrocarbons (jet fuel, mixture of fuels, petrol) diversity of microorganisms is much higher than in case of heavy fractions (grease and oil).

To sum up, obtained results of bioremediation works indicate that applied method for microbial biodegradation of petroleum hydrocarbons is effective and can be recommended for cleaning up petroleum derivatives contaminated soil. The strategy allowed to bioremediate "ex situ" about $30000 \mathrm{t}$ of soil.

The method was patented in 1995.

Table 1.

Comparison of the results of bioremediation of petroleum products contaminated soil.

\begin{tabular}{|c|c|c|c|c|c|c|c|}
\hline $\mathrm{N}^{0}$ & $\begin{array}{l}\text { Sampling } \\
\text { site }\end{array}$ & $\begin{array}{l}\text { Contamina- } \\
\text { ting factor }\end{array}$ & $\begin{array}{l}\text { Primary } \\
\text { hydocar-bons } \\
\text { concentra- } \\
\text { tion } \\
{[\mathrm{mg} / \mathrm{kg}]}\end{array}$ & $\begin{array}{l}\text { Final } \\
\text { hydrocar- } \\
\text { bons } \\
\text { concentra- } \\
\text { tion } \\
{[\mathrm{mg} / \mathrm{kg}]} \\
\end{array}$ & \begin{tabular}{|l} 
Biode- \\
grada- \\
tion \\
effecti- \\
vity \\
{$[\%]$} \\
\end{tabular} & $\begin{array}{l}\text { Reme- } \\
\text { diation } \\
\text { dura- } \\
\text { tion } \\
\text { [days] }\end{array}$ & Remarks \\
\hline $\mathrm{a}$ & b & c & d & $\mathrm{e}$ & $\mathrm{f}$ & $\mathrm{g}$ & $\mathrm{e}$ \\
\hline 1 & $\begin{array}{l}\text { Kielce- } \\
\text { Bialogon }\end{array}$ & $\begin{array}{l}\text { petrol } \\
\text { utilised oils }\end{array}$ & 3000 & 18 & 99 & 120 & \begin{tabular}{|l} 
field \\
research \\
works \\
\end{tabular} \\
\hline 2 & $\begin{array}{l}\text { Kielce- } \\
\text { Bialogon }\end{array}$ & $\begin{array}{l}\text { petrol } \\
\text { utilised oils }\end{array}$ & 2500 & 105 & 90 & 105 & $\begin{array}{l}\text { field } \\
\text { research } \\
\text { works }\end{array}$ \\
\hline 3 & $\begin{array}{l}\text { Kielce- } \\
\text { Bialogon }\end{array}$ & $\begin{array}{l}\text { petrol } \\
\text { utilised oils }\end{array}$ & 1140 & 61 & 90 & 60 & \begin{tabular}{|l} 
field \\
research \\
works \\
\end{tabular} \\
\hline 4 & \begin{tabular}{|l|} 
Tarnowo- \\
Podgórne
\end{tabular} & crude oil & $\begin{array}{l}19059 \\
34790 \\
\end{array}$ & \begin{tabular}{|l|l|}
4600 \\
15400 \\
\end{tabular} & $\begin{array}{l}80 \\
60 \\
\end{array}$ & 75 & \begin{tabular}{|l} 
upper l-r \\
lower l-r
\end{tabular} \\
\hline 5 & \begin{tabular}{|l|}
$\begin{array}{l}\text { Suched- } \\
\text { niów }\end{array}$ \\
\end{tabular} & fuel oil & 2364 & 119 & 95 & 35 & "ex situ" \\
\hline 6 & $\begin{array}{l}\begin{array}{l}\text { Skiernie- } \\
\text { wice }\end{array} \\
\end{array}$ & fuel oil & 2178 & 268 & 88 & 37 & $\begin{array}{l}\text { "ex situ" } \\
\text { "in situ" }\end{array}$ \\
\hline 7 & Radom & fuel oil & 1562 & 247 & 84 & 45 & "ex situ" \\
\hline 8 & Opatów & fuel oil & 7326 & 275 & 96 & 24 & "ex situ" \\
\hline 9 & \begin{tabular}{|l|} 
Kluczewo \\
baza B
\end{tabular} & jet fuel & 3440 & 166 & 95 & 22 & "ex situ" \\
\hline 10 & \begin{tabular}{|l|} 
Kluczewo \\
MPS 4 \\
\end{tabular} & fuel oil & 3131 & 607 & 81 & 74 & "ex situ" \\
\hline 11 & $\begin{array}{l}\text { Kluczewo } \\
\text { MPS } 5\end{array}$ & fuel oil & 1413 & 296 & 79 & 56 & "ex situ" \\
\hline $\mathrm{a}$ & $\mathrm{b}$ & c & d & e & $\mathrm{f}$ & $\mathrm{g}$ & e \\
\hline 12 & Kluczewo & jet fuel & 31400 & 89.7 & 99.7 & 30 & "ex situ" \\
\hline
\end{tabular}




\begin{tabular}{|l|l|l|l|l|l|l|l|}
\hline & pipeline & & & & & & \\
\hline 13 & Retki & petrol & 2096 & 400 & 81 & 80 & $\begin{array}{l}\text { "in situ" } \\
\text { (clay) }\end{array}$ \\
\hline 14 & Retki & petrol & $386 \mathbf{d}$ & 250 & 93.5 & 80 & $\begin{array}{l}\text { "in situ" } \\
\text { (sand) }\end{array}$ \\
\hline
\end{tabular}

Table 2.

Abundance of bacterial strains in soil correlated with different fractions of petroleum derivatives as contaminating factors.

\begin{tabular}{|c|c|c|c|c|}
\hline $\begin{array}{l}\text { Contamina- } \\
\text { ting factor }\end{array}$ & $\begin{array}{l}\text { Sampling } \\
\text { site }\end{array}$ & Dominants & $\begin{array}{l}\text { Type of } \\
\text { soil }\end{array}$ & $\begin{array}{l}\% \text { of hydrocarbons } \\
\text { utilising bacteria in } \\
\text { the total number of } \\
\text { bacteria in soil }\end{array}$ \\
\hline $\mathrm{a}$ & $\mathrm{b}$ & c & d & $\mathrm{e}$ \\
\hline Jet fuel & Airport & $\begin{array}{l}\text { Comamonas testostroni } \\
\text { Pseudomonas alcaligenes } \\
\text { Bacillus sp. } \\
\text { Chromobacterium } \\
\text { violaceum } \\
\text { P. fluorescens } \\
\text { Agrobacterium radiobacter } \\
\text { Flavobacterium } \\
\text { indologenes }\end{array}$ & Clay / sand & $0.2-2.2$ \\
\hline $\begin{array}{l}\text { Mixture of } \\
\text { fuels }\end{array}$ & Petrol station & \begin{tabular}{|l|} 
Micrococcus varians \\
Staphylococcus \\
saprophiticus \\
Acinetobacter lwoffii \\
Pseudomonas diminuta \\
Micrococcus sp. \\
Bacillus pasteurii \\
\end{tabular} & Sand & $0.0 \mathrm{~d}-0.29$ \\
\hline Petrol & $\begin{array}{l}\text { Cultivated } \\
\text { soil }\end{array}$ & $\begin{array}{l}\text { Agrobacterium radiobacter } \\
\text { Micrococcus kristinae } \\
\text { Micrococcus varians }\end{array}$ & Clay / sand & $0.01-0.14$ \\
\hline $\begin{array}{l}\text { Grease } \\
\text { and oil }\end{array}$ & $\begin{array}{l}\text { Transfer } \\
\text { railway } \\
\text { station }\end{array}$ & $\begin{array}{l}\text { Pseudomonas stutzeri } \\
\text { P. fluorescens } \\
\text { Bacillus pasteuri }\end{array}$ & Clay / sand & $0.03-1.09$ \\
\hline
\end{tabular}




\section{REFERENCES}

1. Atlas R.M. (1995). Bioremediation - Special Report. C\&EN American Chemical Society, 3.

2. Biochemistry of Microbial Degradation. (1994). Ed. Ratledge C. Kluwer Academic Publishers.

3. International ISO Standard, Polish version (1994). 11266: (E).

4. Lebkowska M. (1996).Application of microorganisms for petroleum products biodegradation in soil. Gaz, Woda i Technika Sanitarna, 3.

5. Morgan P., Watkinson R.J.(1989). Hydrocarbon degradation in soils and methods for soil biotreatment. Critical Rev. Biotechnol., 8. DOl: https://doi.org/10.3109/07388558909148196

6. Pitter P., Chudoba J. (1990). Biodegradability of organic substances in the aquatic environment. CRC.

7. Radwan S.S. et al. (1997). A feasibility study on seeding as a bioremediation practice for the oily Kuwaiti desert. J. of Applied Microbiology, 83.

DOl: https://doi.org/10.1046/j.1365-2672.1997.00237.x

8. Methodological guidelines for estimation petroleum products and other chemicals contamination in soil and ground water for the bioremediation works. (1995). State Environmental Inspectorate, Warsaw. 